\title{
A study of new NEK8 mutations in patients with severe renal cystic hypodysplasia and ciliopathy-associated defects
}

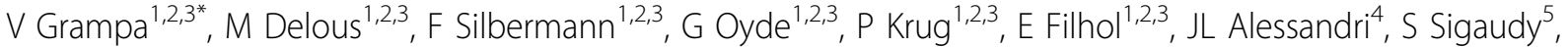 \\ R Bouvier $^{6}$, MT Zabot ${ }^{6}$, C Antignac ${ }^{1,3,7}$, M Gubler ${ }^{1,2,3}$, T Attié-Bitach ${ }^{1,2,7}$, A Benmerah ${ }^{1,2,3}$, C Jeanpierre ${ }^{1,2,3}$, \\ S Saunier ${ }^{1,2,3}$
}

From Cilia 2014 - Second International Conference Paris, France. 18-21 November 2014

NEK8/NPHP9 encodes a NIMA (Never-In-Mitosis A) protein essential for cell cycle control. NEK8 is composed of kinase and RCC1 domains, the latter involved in centrosomal localization. It localizes into the nucleus and at the inversin compartment in the primary cilium. Using ciliary gene-enriched exome sequencing, we identified recessive NEK8 mutations in 3 cases with severe overlapping phenotypes including renal cystic (hypo)dysplasia, situs inversus, cardiopathy and paucity of bile ducts. Two patients who died early after birth carried missense mutations in the kinase and/or RCC1 domains. A homozygous splice mutation was identified in a fetus with Meckel-like phenotype. Analyses of patient fibroblasts and IMCD3 cells expressing mutated NEK8-GFP revealed that the mutations affect NEK8 nuclear and ciliary localization. The number of ciliated cells was reduced and ciliary localization of NEK8 partner ANKS6/ NPHP16 was lost, demonstrating the key role of NEK8 in cilia function. Surprisingly, in patient fibroblasts, NEK8 accumulates at the Golgi that appeared dispersed into the cytoplasm suggesting a role in vesicular trafficking. Cell cycle defects associated with abnormal nuclear accumulation of YAP, a transcriptional co-activator of the Hippo pathway was also observed, together with dysregulation of several Hippo effector/target genes. Finally, injection of nek8 morpholinos in zebrafish embryos led to ciliopathy-related phenotype (curly body axis, laterality defects, pronephric cysts) that could be rescued by RNA expression of WT NEK8 but not by the mutated forms,

${ }^{1}$ INSERM U1163, Institut IMAGINE Laboratory of Inherited Kidney Diseases, Paris, France

Full list of author information is available at the end of the article further demonstrating pathogenicity of the mutations. Altogether, we demonstrate that human NEK8 mutations alter developmental ciliary and non-ciliary processes, thus leading to multisystemic defects.

\section{Authors' details}

'INSERM U1163, Institut IMAGINE Laboratory of Inherited Kidney Diseases, Paris, France. ${ }^{2}$ INSERM U781, Institut IMAGINE, Hôpital Necker-Enfants Malades, Paris, France. ${ }^{3}$ Paris Descartes-Sorbonne Paris Cité University, Institut IMAGINE, Paris, France. ${ }^{4}$ Réanimation Néonatal et Infantile, Centre Hopitalier Felix Guyon, St. Denis, Réunion, France. ${ }^{5}$ Département de Génétique Médicale, Hopital de la Timone, Marseille, France. ${ }^{6}$ Centre de Biologie et de Pathologie Est, Bron, France. ${ }^{7}$ APHP - Département de Génétique, Hôpital Necker-Enfants Malades, Paris, France.

Published: 13 July 2015

\section{doi:10.1186/2046-2530-4-S1-P54}

Cite this article as: Grampa et al:: A study of new NEK8 mutations in patients with severe renal cystic hypodysplasia and

ciliopathy-associated defects. Cilia 2015 4(Suppl 1):P54.

\section{Submit your next manuscript to BioMed Central} and take full advantage of:

- Convenient online submission

- Thorough peer review

- No space constraints or color figure charges

- Immediate publication on acceptance

- Inclusion in PubMed, CAS, Scopus and Google Scholar

- Research which is freely available for redistribution 